$551.3111-$

$552(777)$

SOME LARGE BOWLDERS IN THE KANSAN DRIFT OF SOUTHERN IOWA

BY

GEORGE F. KAY 


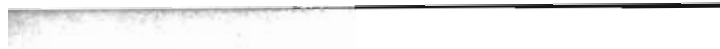




\section{SOME LARGE BOWLDERS IN THE KANSAN DRIFT OF SOUTHERN IOWA}

Many times the fact has been emphasized that the number of large bowlders on the surface of the Kansan drift is small when compared with the number on the surface of the Iowan drift. In fact, as has been pointed out by Alden and Leighton ${ }^{2}$, there was at one time among some geologists the general impression that if large bowlders of coarse, feldspathic granite were found associated with a drift, that drift was presumably the Iowan and should be so mapped. However, many years ago large bowlders

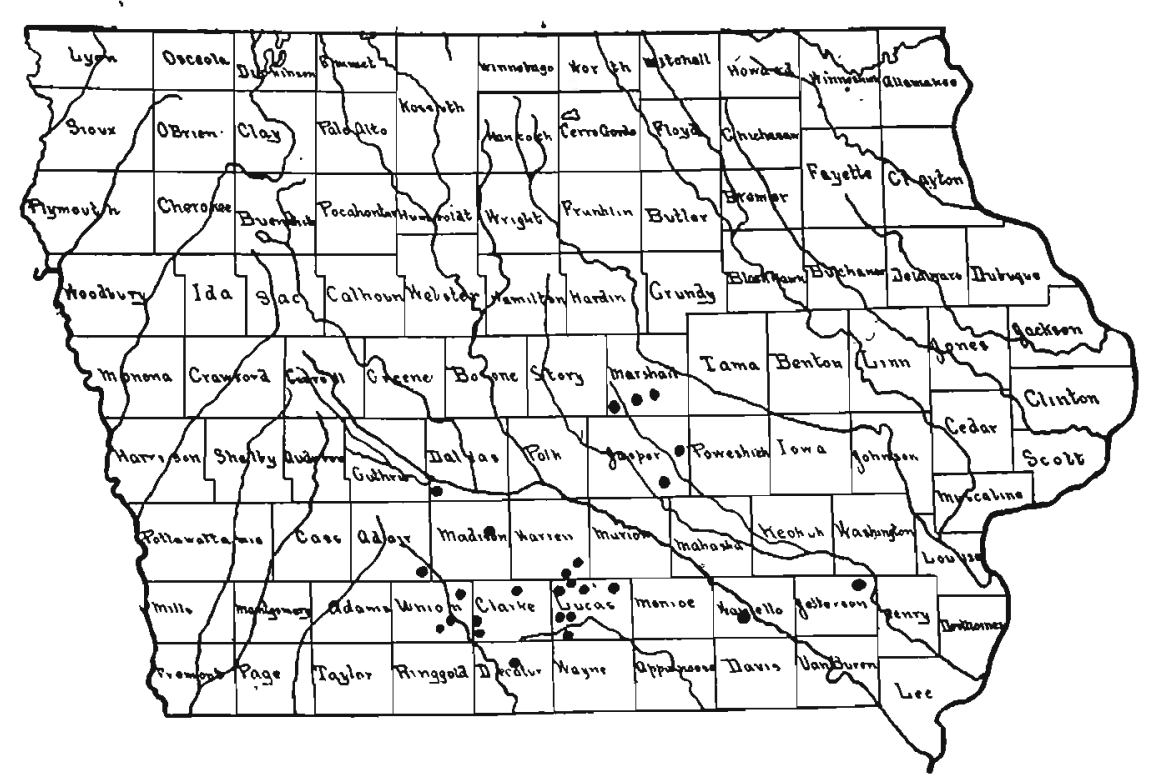

Fig. 40.-Map showing distribution of some large bowlders in Kansan drift in southern Iowa.

${ }^{1} I$ owa Greological Survey, Vol, XXVI, p. 126. 


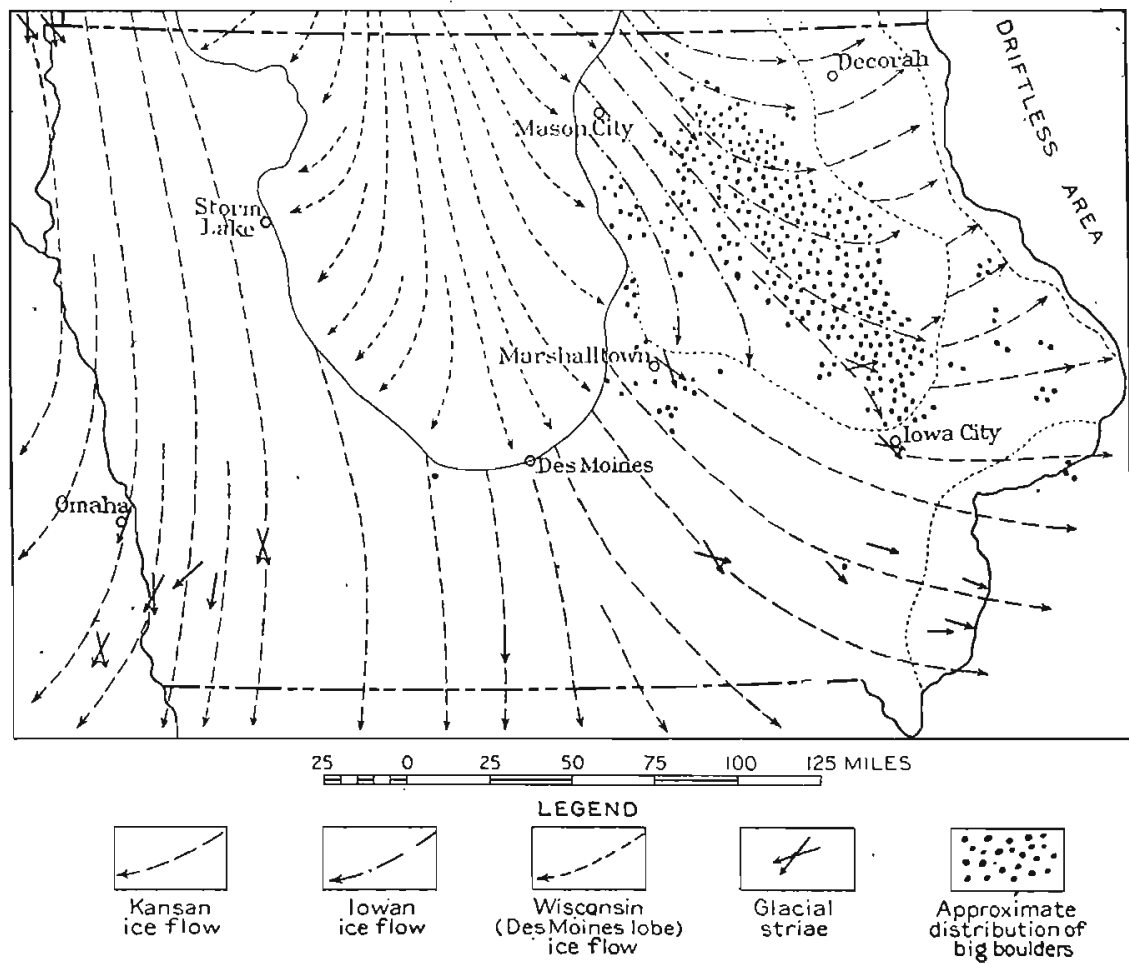

Fig. 41.-Diagram showing the distribution of big granite bowlders as related to the distribution of the lce sheets in Iowa.

which are within the area of Kansan drift and many miles from any well recognized area of Iowan drift were described in reports of the Iowa Geological Survey and in other publications.

Recent studies of the Kansan drift of southern Iowa have revealed the presence of more large bowlders than had been antici. pated, and no doubt if an attempt were made to locate all bowlders of large size the number now known could be increased considerably. It seems well at this time to make record of the locations and sizes of large"bowlders in the Kansan drift area for, one by one, they will be destroyed, some by the farmers in better preparing the farms for cultivation, and some for use in foundations of buildings and for abutments of bridges. A few are being removed to parks and other places to serve as memorials of: important events in the history of the state. In figure 40 , there are represented only some of the largest bowlders, some of which 
have been described in former publications; some are described here for the first time. Figure 41, when compared with figure 40 , shows graphically in a general way the relative numbers of bowlders in the Iowan and Kansan areas.

In the Kansan drift of southern Iowa the largest bowlder known to the writer is in the northwest quarter of section 15 , Otter Creek township, Lucas county. It is 25 feet long, 20 feet wide, and is exposed for 16 feet above the surface, figure 42 . In this connection it may be of interest to state that the largest bowlder known in the Iowan drift area is in the northwest quarter of the southwest quarter of section 22 , Riverton township, in Floyd county. Its dimensions are 50 feet by 40 feet by $111 / 2$ feet above ground. A smaller piece which is beside it, and which is apparently a fragment of the larger, measures 17 feet by 7 feet by $1 \frac{1}{2}$ feet.

The writer has seen no large granite bowlders in the southwestern part of the state. It is worthy of mention, however,

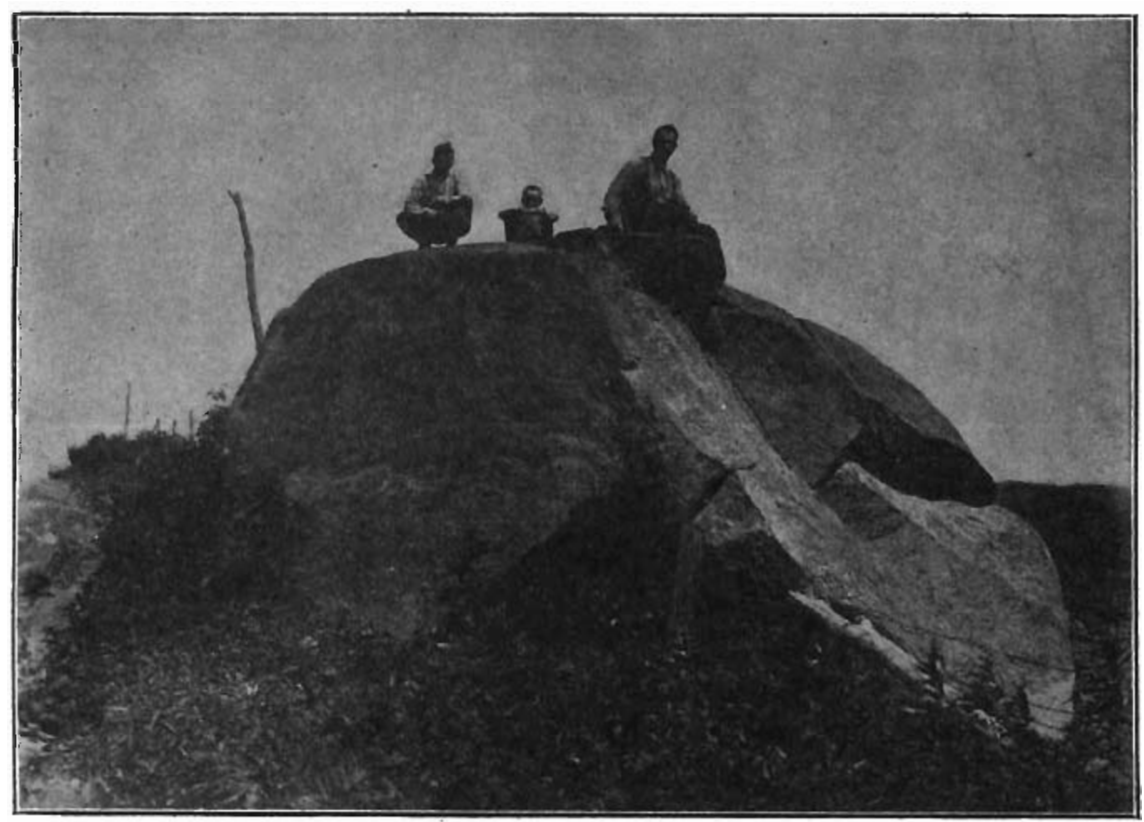

FIG. 42.-Large granite bowlder in the northwest quarter of section 15, Otter Creek township, Lucas county. 
that Mr. F. H. Reed, a farmer living a few miles northeast of Yorktown, furmished information to the effect that in section 15, Morton township, Page county, there used to be a granite bowlder on the McCormick farm close to Lone Rock school, which school received its name from the presence of the bowlder. It was 20 feet long, 20 feet wide, and 5 fect high. Mr. Reed stated also that a bowlder with dimensions of 6 feet by 8 feet by 3 feet

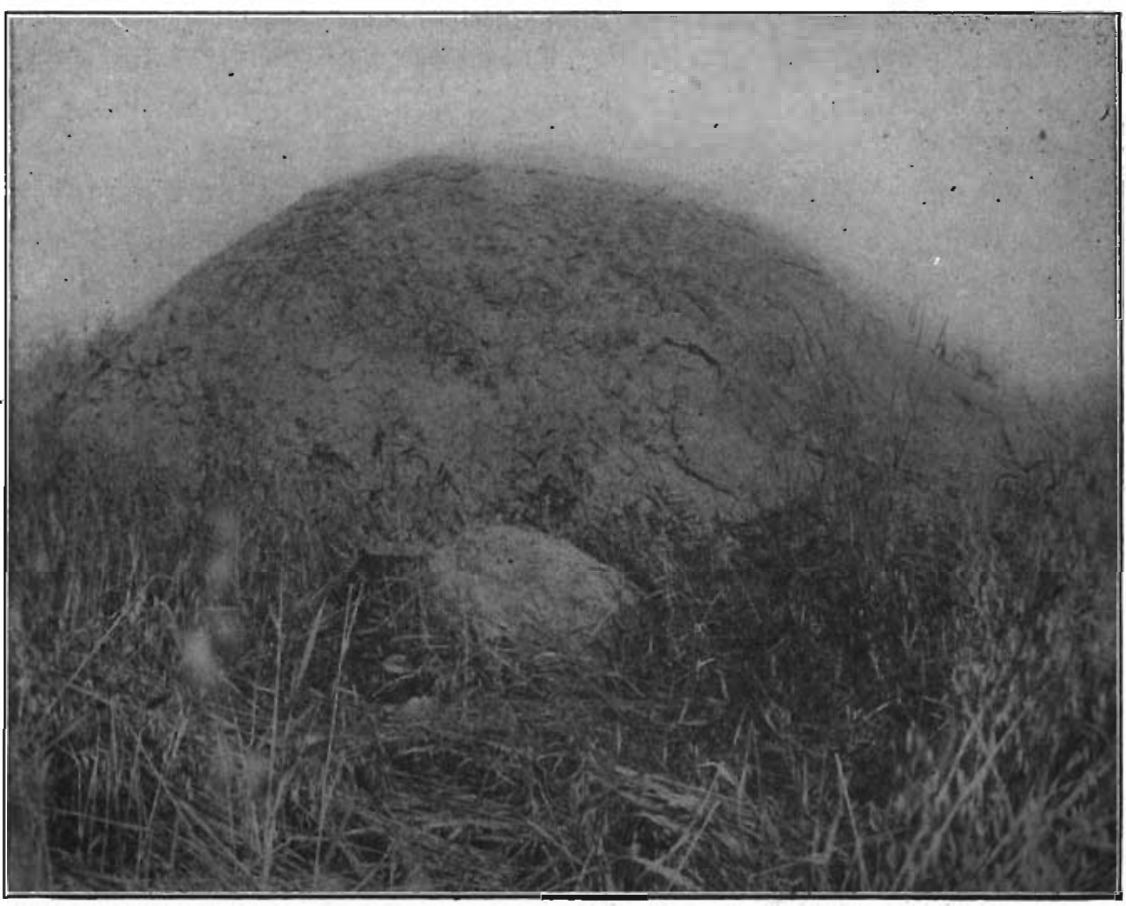

Fig. 43.-Large granite bowlder in the southeast quarter of section 13, Liberty township, Lucas county.

had been blasted from the northeast quarter of section 34, Morton township, Page county. In the park at College Springs there is now a bowlder of Sioux quartzite with dimensions 6 feet by 4 feet by 3 feet. In this part of the state the loess in many places is sufficiently thick to cover from view such large bowlders as may lie on the Kansan drift. 


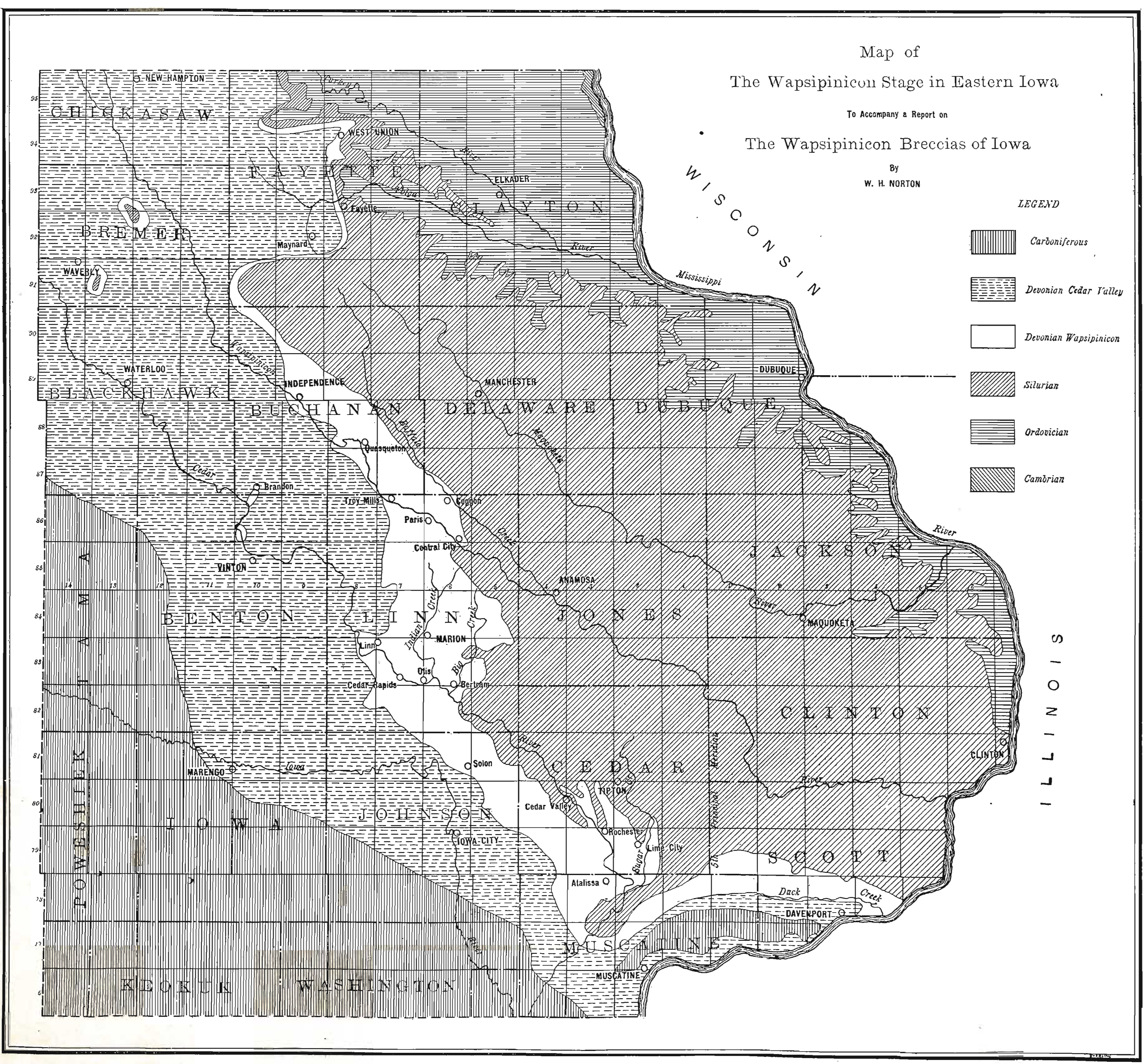


There is given below a brief description of some of the large bowlders in Kansan drift in southern Iowa. Attention is calle to the publications in which previous reference has been made to some of these bowlders.

It will be observed that nearly all of the large bowlders are granite; a few are quartzite.

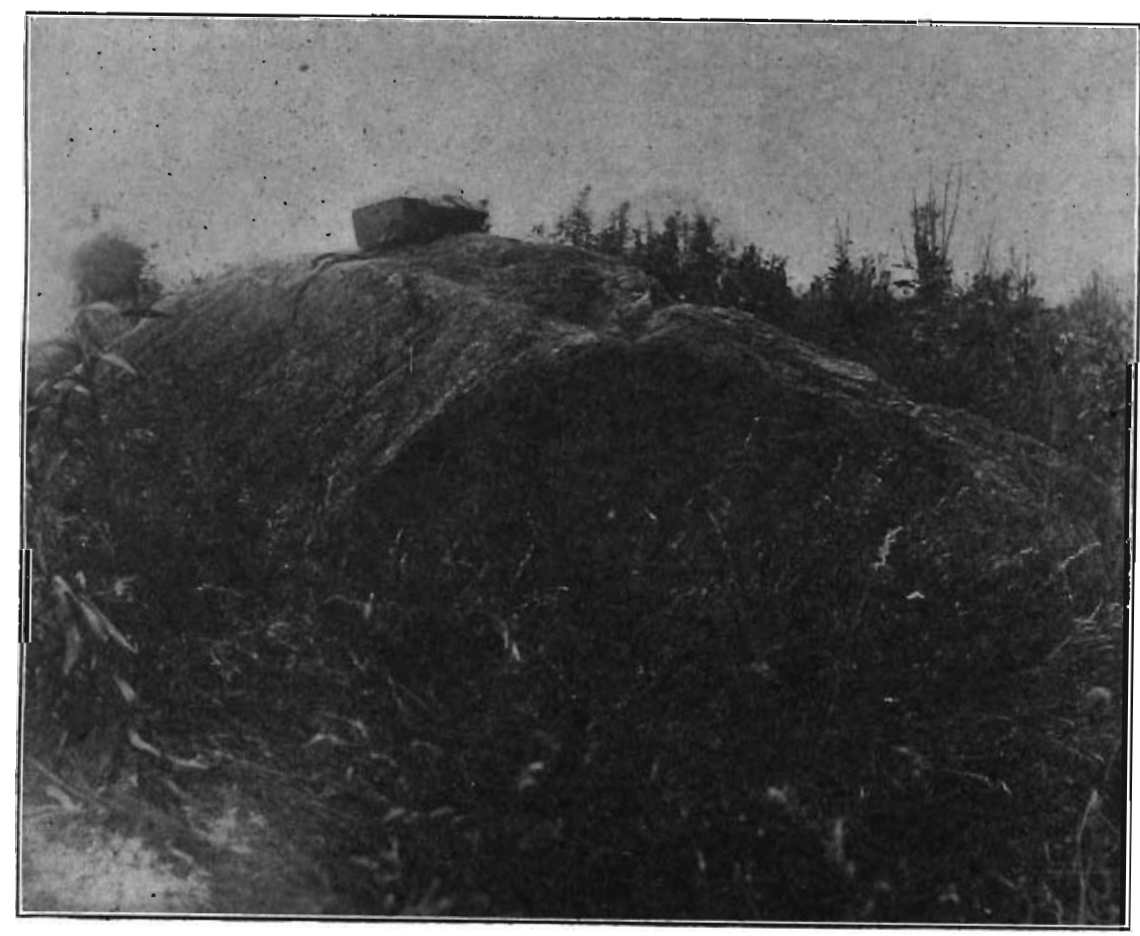

FIG. 44.- Large granite bowlder in the northeast quarter of the northwest quarter of section 33, New Hope township, Union county. 


\begin{tabular}{|c|c|c|c|c|}
\hline COUNTY & LOCATION IN COUNTY & Kynd of Rock & Size & REFERENCE \\
\hline 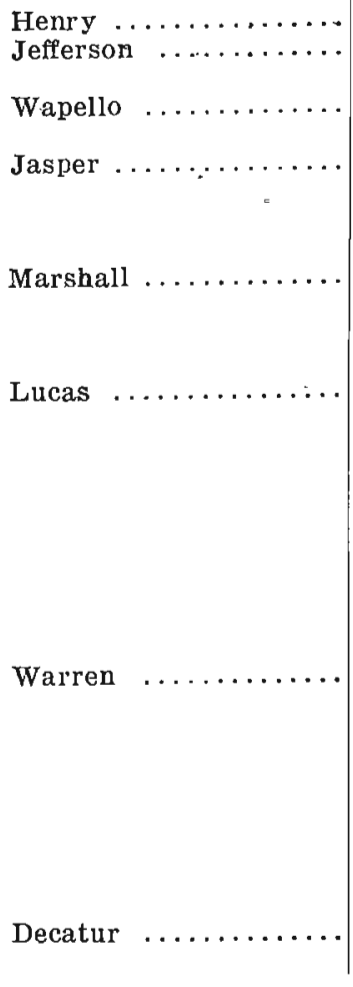 & 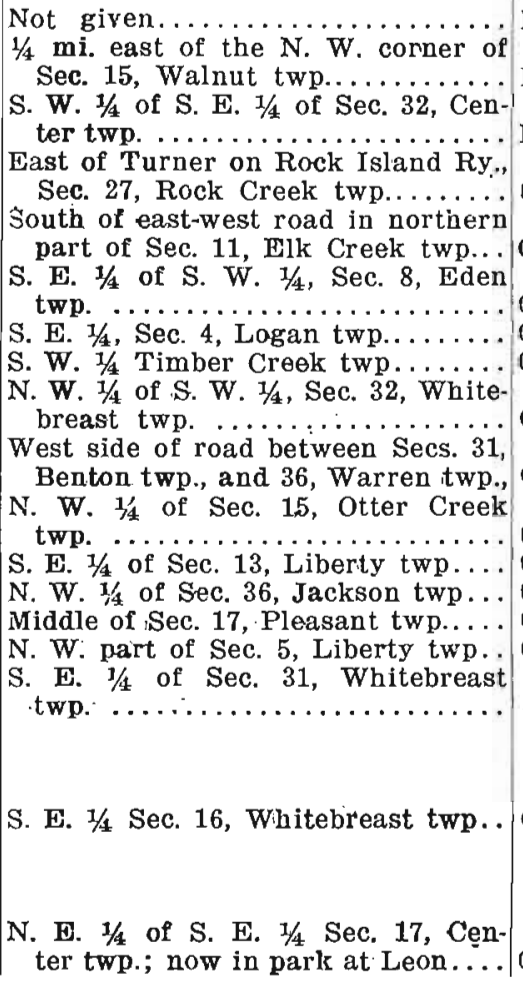 & 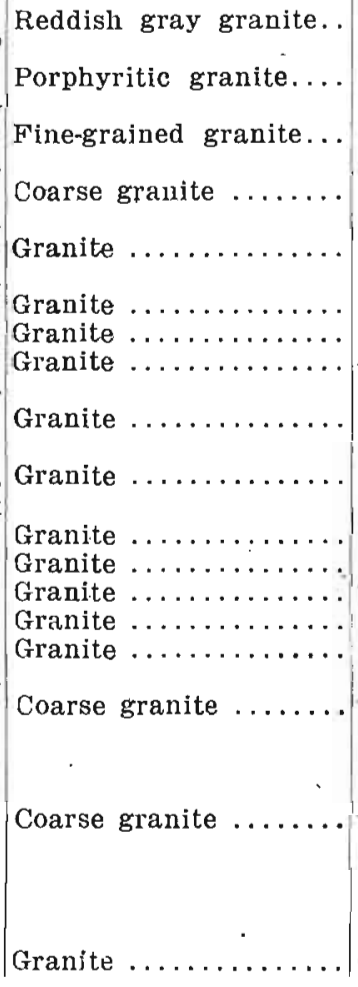 & 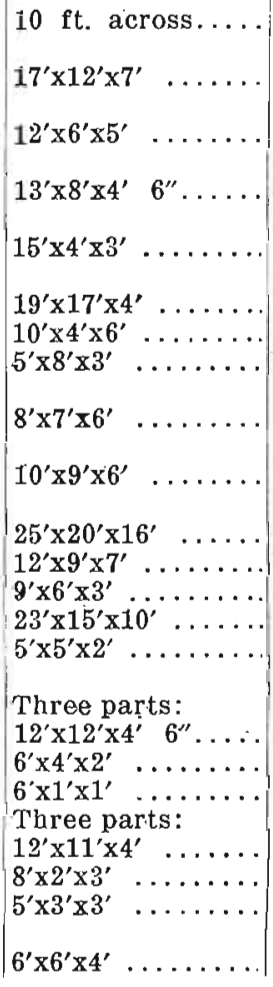 & $\begin{array}{l}\text { Ia. Geol. Sur. Vol. XII, } \\
\text { p. 290, 1902. Vol. XII, } \\
\text { Ia. Geol. Sur. Vol. X. } \\
\text { p. 427, 1902. } \\
\text { Ia. Geol. Sur. Vol. XII, } \\
\text { p. 472, 1902. } \\
\text { Ia. Geol Sur. Vol. XXV1, } \\
\text { p. } 127 \text {. } \\
\text { - } \\
\text { See figure } 42 . \\
\text { See figure } 43 .\end{array}$ \\
\hline
\end{tabular}




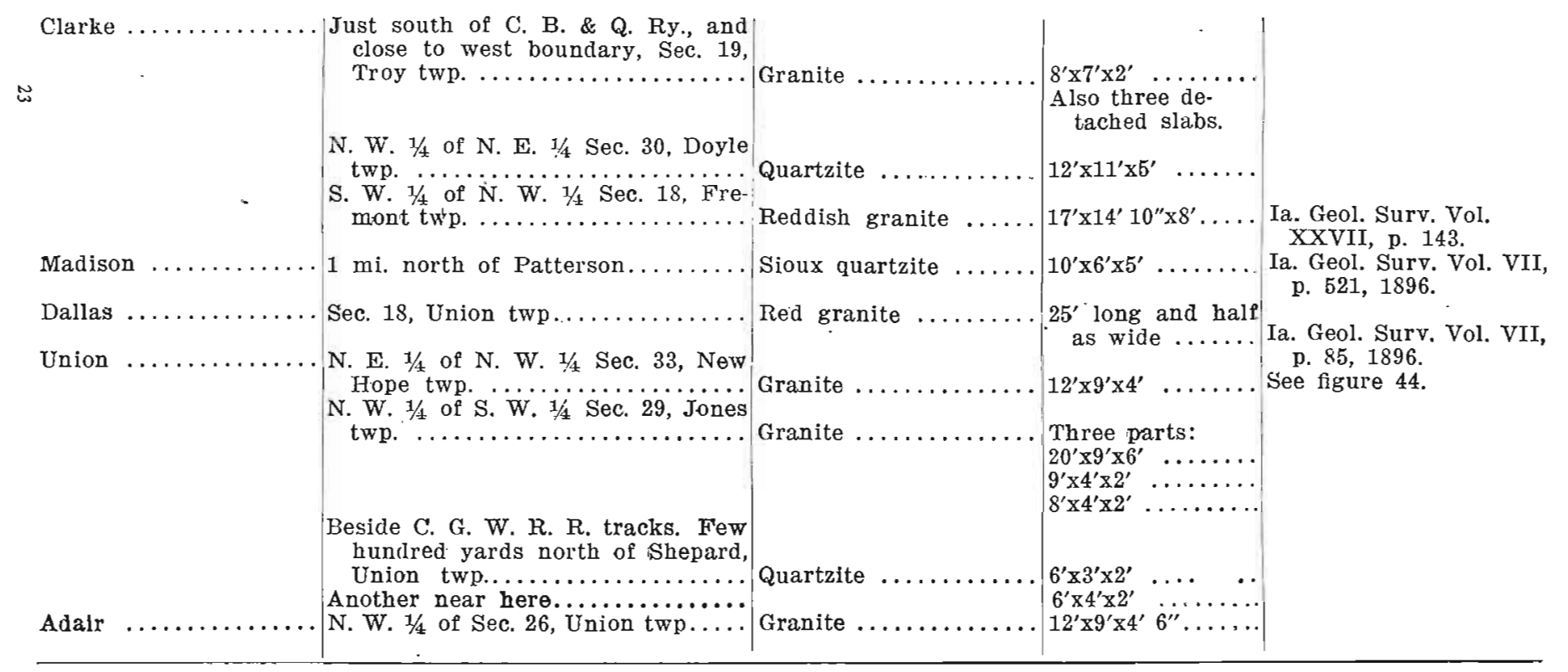


' 